\title{
IMPROVING STUDENTS’ WRITING: WHY IS THERE A NEED FOR TEACHER FEEDBACK
}

\author{
Clarence Jerry ${ }^{1}$, Jariah Mohd Jan ${ }^{2}$, and Moses Samuel ${ }^{2}$ \\ ${ }^{1}$ Universiti Malaysia Sarawak and ${ }^{2}$ University of Malaya
}

\begin{abstract}
Feedback on students' written work has always been examined by interested second language (SL) researchers and practitioners. The way a teacher provides feedback will have direct impact on whether students become successful or unsuccessful writers. Feedback provides students the opportunity to revise their written work which is crucial to their development as writers. This paper discusses some of the researched issues related to teacher feedback to students' writing, types of teacher written feedback, the impact of teacher feedback and also teachers' role in providing feedback. An insight into what teacher feedback entails will reveal how feedback can play a central role in increasing the learner's achievement in writing.
\end{abstract}

\section{KEYWORDS: WRITING ASSESSMENT, TEACHER FEEDBACK, SECOND LANGUAGE STUDENTS' WRITING}

\section{Introduction}

The classroom is the context for literacy learning and it is necessary for teachers to not only examine their teaching and assessing behaviours, but also ask themselves if they implicitly allow their students to be who they explicitly encourage them to be. There may be numerous channels by which teachers respond to students' ideas, but written feedback seems to be the most common teacher response to students work. In fact, teacher's written feedback is an essential aspect in any English language writing course. Teachers were often encouraged to adopt a process-oriented pedagogy with students ideally drafting, editing, revising, and redrafting their work. In process instruction, writing development involves a number of skills including generating ideas, organisational schemes, and goals; transforming ideas into language and its orthographic representation; and rewriting text to improve it (Berninger, Fuller, \& Whitaker, 1996).

A majority of second language (L2) teachers would accept the fact that responding to student writing is one of the most challenging aspects of their job. Many L2 teachers express their concerns that reading essays or homework written by students and providing written commentary is timeconsuming as well as exhausting. Nevertheless, the practice of providing written feedback has been widespread among L2 teachers for various reasons. Many teachers believe that their written comments will help student writers to improve their writing; some teachers provide written comments to justify the grade they assigned; others feel obliged to provide substantial written comments to show appreciation of students' efforts; still other teachers try to provide more comments 


\section{IMPROVING STUDENTS’ WRITING: WHY IS THERE A NEED FOR TEACHER FEEDBACK}

because it is known that many L2 students greatly appreciate written commentary from their teachers and strongly want to be corrected as much as possible.

While there are also efforts to substitute teachers' feedback with other responses such as peers' feedback or computerised comments, studies have shown that feedback given by the teachers are more useful in helping the students to improve their writing skills (Sarah et al., 2010). This is perhaps due to teachers' wealth of experience that can provide accurate feedback on students' mistakes or writing problems. As such, there is an apparent need to value teachers' feedback as part of the repertoire to improve students' writing.

\section{Research on written feedback}

Studies on writing suggest that feedback plays a central role in increasing the learner's achievement. It is important for the learners to do well in the writing tasks and it is also equally important for ESL teachers to assess their students' writing and provide immediate feedback to ensure that the learners progress in their learning process (Clarence J., Moses S. and Jariah Mohd. Jan, 2011: 251; Ferris, 1997; Graves, 1983). The way a teacher provides feedback will have direct impact on whether students become successful or unsuccessful writers. Sommers (1982) believes that a teacher's written feedback could cause a student to revise his or her written work, resulting in the student producing a different piece of writing in the next draft. Apart from that, novice writers need guidance to evaluate, modify, or restructure their ideas and to add and delete content to improve their writing (Keppner, 1991; Olson \& Raffeld, 1987). On the same note, Ferris (1997) concurs that teacher feedback enables students to expand and shape their ideas over subsequent drafts of their work. Thus, with teacher assistance and feedback, students become better writers by gradually appropriating the skills necessary to critically view and revise their own work (Zellermayer, 1989).

Learners of writing need to know when they are performing well and when they are not (Zellermayer, 1989). The more information learners have about their writing, the better they understand how to perform in a better way (Cardelle \& Corno, 1981). Learners of writing need feedback, not only to monitor their own progress, but also to take other's view and adapt a message to it (Flower, 1979). An additional effect of corrective feedback may be the enhancement of learners' metalinguistic awareness (Swain, 1995), an important step in their appropriation of the written system.

Teacher feedback, particularly written teacher feedback, also has a number of characteristics of interest for ongoing research into writing development. It is a key site of knowledge construction between expert and novice, a time when teachers are most likely to provide explicit, form-focused, and individualized instruction to student writers. Teacher feedback brings into focus the language choices writers need to make to convey their ideas and often reinforces instructional points discussed in whole-class settings (Orellana, 1995; Wollman-Bonilla, 2000).

The issue of responding to students' work has been reviewed widely (e.g. Ferris et al., 1997; Moxley, 1989; Straub, 1997; Zamel, 1985). Patthey-Chavez and Clare (1996) investigated longitudinal development in the writings of five bilingual fourth graders and found a clear teacher influence on that development but did not pay attention to written teacher feedback between drafts. Orellana (1995) probed complex relations between teacher attitudes and the development of student writing in two very different inner-city classrooms but again did not focus on written teacher feedback between drafts. 


\section{IMPROVING STUDENTS’ WRITING: WHY IS THERE A NEED FOR TEACHER FEEDBACK}

Most research on written teacher feedback has focused on college students in general and college students who are second-language learners specifically (Ferris, 1997; Keppner, 1991; Olson \& Raffeld, 1987; Zamel, 1985). For these students, researchers generally have found that teacher feedback about content (i.e., comments that encourage students to add and delete content and/ or restructure content) as opposed to teacher feedback about surface features (i.e., word choice, spelling, grammar, and punctuation) during the revision process is associated with higher-quality revisions (Keppner, 1991; Olson \& Raffeld, 1987). Ferris (1997), similarly, found that certain types of written comments appeared to lead to more successful revisions for college students who were Englishlanguage learners. For example, teacher requests for information, summary comments on grammar, and text-specific comments on earlier drafts of student work appeared to lead to more successful revisions, whereas statements that provided information to students and less specific comments were less successful.

Most L2 specialists, regardless whether or not they support error correction, agree that previous studies were essentially not comparable (Ellis, 2009; Ferris, 2004; Guenett, 2007). For example, they attributed the contradictory findings of studies on error correction to inconsistent research designs and procedures as well as extraneous variables beyond the control of or not properly controlled by the researchers. Regarding research design, Guenett (2007) pointed out the three main sources of the incomparability: variance in population (proficiency levels and measurement of student proficiency), lack of a real control group, and lack of longitudinal studies to indicate long-term effects of correction. With respect to methodology, Guenett regarded variance in treatment, procedures, and measurement of accuracy as the major sources of the difference in findings. Consequently, autonomy Guenett concluded that the studies were incomparable because of inconsistent design and methodology and suggested that the effect of corrective feedback depends on various factors including "classroom context, the type of errors students makes, their proficiency level, the type of writing they are asked to do, and a collection of other variables that are as of yet unknown" (ibid.: 52).

Similarly, many recent scholars acknowledge the influence of contextual factors on effectiveness of corrective feedback (Goldstein, 2004; 2005). Hyland and Hyland stated that "what is effective feedback for one student in one setting is less so another" (2006, p. 88). Ellis (2009, p. 106) commented that "the search for the best way to do written CF may in fact be fundamentally mistaken if it is accepted that CF needs to take account of the specific institutional, classroom and task contexts".

In addition, Lee (2008, p. 81), after examining the written feedback practices of 26 Hong Kong secondary English teachers and finding that “teachers' feedback practices are influenced by a myriad of contextual factors including teachers' beliefs, values, understandings, and knowledge, which are mediated by the cultural institutional contexts, such as philosophies about feedback and attitudes to exams, and socio-political issues pertaining to power relations and teacher, likewise pointed to the complexities involved in trying to account for contextual factors.

\section{Types of written teacher feedback}

Teachers usually have the choice to give both instructional and evaluative feedback on students' written work. However, the most common choice of teacher's feedback include descriptive written commentary, comments for revising major content and organization of the essay, and prose-editing responses on major editorial weaknesses (Williams, 2003). Basically, there are two common types of feedback: feedback on form and feedback on content. In feedback on form, the teacher would tend to 


\section{IMPROVING STUDENTS’ WRITING: WHY IS THERE A NEED FOR TEACHER FEEDBACK}

correct surface errors pertaining to language use. On the other hand, in feedback on content, the teacher's focus would be in getting the students to put their thoughts clearly in writing, so that the message can be clearly understood by the reader.

When focusing on form, teachers would typically be looking at the students' writing at the sentence level. Williams (2003) identifies three types of teacher feedback which focuses on form. The first type is where the teacher overtly marks and corrects students' errors. Another type is where the teacher indicates the place and type of error. This sometimes involves the use of error-indicating codes such as the use of 'sva' for a subject-verb-agreement error. The last type is where the teacher merely underlines specific places at the sentence to indicate the presence of errors. Ferris et al. (1997) also discuss the form or linguistic features (or form) of teacher comments, and they suggest three variables: (1) its syntactic form (question, statement, or imperative), (2) the presence or absence of hedges in the comment, and (3) its specificity (text-specific or generic).

Feedback on content primarily involves the teacher making comments on the clarity of the message or on the cohesiveness of the text. A frequent response was to reword the student's text when it was not clear (Fregeau, 1999). Another would be to write comments in the margins or at the end of the students' written work (Bardine, 2000).

Other researchers had different ways of categorising feedback or comments. For instance, Caulk (1994) in his study suggests that comments can be divided into six categories such as the following:

(1) form - suggestions to change introductions, conclusion, and paragraphs so they would be closer to typical English form (for instance, making the general point clear in the introduction, not bringing up new arguments in the conclusion, etc.);

(2) reorganisation - suggestions to change the order of words, phrases, sentences, and paragraphs for reasons not due to form;

(3) more information - suggestions to write more detailed information about one aspect of the paper;

(4) write less - suggestions to write less information about one aspect of the paper;

(5) clarity - statements that the meaning of a particular sentence, point, or paragraph is unclear to the reader and suggesting it to be made clearer; and

(6) style - suggestions that the style of a particular sentence or passage is not the most effective for that particular writing task.

In another instance, Olson and Raffeld (1987) categorize the type of feedback students received on each draft as surface level, clarification level, or content level. Surface-level feedback included all edits and comments students received that pertained to mechanics, usage, grammar, spelling, sentence structure, or format. Clarification-level feedback was defined as teachers' directions to students to clarify or elaborate on specific words. Content feedback was defined as teachers' comments pertaining to the concepts in and structure of students' writing. This type of feedback included comments to delete, reorganize, or add information, as well as questions intended to challenge students' thinking. This category of feedback also could include genre-specific comments or edits.

In the L2 scenario, Ellis (2009) proposed a typology of the different types of written corrective feedback available to teachers and researchers. The typology distinguishes two sets of options relating to (1) strategies for providing feedback (for example, direct, indirect, or meta-linguistic feedback) and (2) the students' response to the feedback (for example, revision required, attention to 


\section{IMPROVING STUDENTS’ WRITING: WHY IS THERE A NEED FOR TEACHER FEEDBACK}

correction only required). The typology clearly indicates that teachers are providing different types of responses when assessing or marking students' writing though they might not be fully aware of what they have written on the students' written piece.

\section{Impact of teacher feedback}

There are positive and negative effects derived from the form-focused feedback. On a positive note, form-focused feedback was found to significantly improve a student's grammatical score on subsequent rewrites produced by the students (Fathman \& Walley, 1990; Frodesen, 2001; Dana et al., 2011). A better understanding of feedback could turn the situation into ground for teachers and students to engage in a dialogue that seeks to "understand the different assumptions regarding texts, writers, audiences and knowledge that writers can have” (MacKay, 1993, p. 78).

However, such feedback could be a source of miscommunication and misunderstanding (Hyland, 1998) and thus, would not be able to help develop a student's writing skills. In theory, constructive feedback provides learners with means of understanding their readers' needs, but in practice, most learners do not receive such feedback (Zellermayer, 1989). Research findings from second language classrooms indicate that writing teachers are mainly concerned with responding to surface level features and mechanical errors. Such feedback is likely to be ineffective, confusing, inconsistent and contradictory (Zamel, 1985; Robb, Ross \& Shortreed, 1986; Cohen, 1987). A number of writing instruction theorists (Semke, 1984; Sommers, 1982) have pointed out that feedback provided and processed inadequately may inhibit the learner's motivation for writing.

Williams (2003) points out that when students merely copy teacher corrections, they become passive and are not able to recognise, nor correct errors on their own. Allwright (1975) in his study observes that error treatment in the classroom is imprecise, inconsistent, and ambiguous. Fanselow (1977) also has similar findings in his analysis of the corrective techniques of 11 teachers in adult ESL classroom. He discovered that feedback was confusing to learners in that learner often received contradictory signals simultaneously with respect to the content and the form of their utterance. Kittredge (2002) is of the opinion that such feedback would mislead the students into believing that the teacher has done all the necessary work, making it unnecessary for the students to revise the written work beyond the corrections indicated by the teacher. Fregeau (1999), in her study, discovered that students' writing skills were not enhanced even when a teacher merely indicated the presence or types of errors without correcting them. This was because the students did not understand why the errors were indicated and simply guessed what corrections were to be made.

Where content is addressed, a problem may occur if a teacher were to impose his or her values and understanding on the students' writing ( $\mathrm{Li}, 1995)$. A teacher in an attempt to correct the content will impose his or her perceived 'ideal text' on what the writer really wants to say. This effort on the teacher's part is fairly time consuming and also 'risky' activity. According to Berg, Admiraal and Pilot (2003), there is a possibility of misinterpretation and thereby commenting or correcting errors in a way that changes the meaning that the writer intended. Sometimes, problems could also arise when teachers write vague comments in the margins or at the end of a student's written work. Vague comments such as "Very good", "Nice, but redo" often confuse students rather than help them revise their writing (Fregeau, 1999). These comments do not give any specific suggestions or directions to students about how to proceed in their revision of text. Leki (1990) found that students' responses to teachers' feedback on content is also quite discouraging. It was found that some students do not read the comments at all. Some students may read the comments but do not understand what the comments mean, whilst others may read and understand the comments but do not know how to respond to the comments. 


\section{IMPROVING STUDENTS’ WRITING: WHY IS THERE A NEED FOR TEACHER FEEDBACK}

There is also a need to look at the students' perception on teacher's feedback or comments. Cohen (1987) surveyed 217 college students composed of ESL students, English-speaking foreign language students, and native-English-speaking students in English composition classes. The students perceived that their teachers focused mainly on local aspects of student writing when providing feedback (that is, sentence level issues rather than content or rhetorical issues). Also, the students responded that they often faced problems in understanding and using teacher feedback due to confusing teacher comments. Therefore, Cohen concluded that teacher feedback had less impact on the students than teachers would have expected. Though Cohen's study has several shortcomings, including the use of heterogeneous subjects, his study was ground breaking in the field by examining student perceptions and provided a foundation for subsequent studies.

Slightly modifying Cohen's initial study, Cohen and Cavalcanti (1990) investigated teacher comments as well as 9 EFL college students in Brazil. In line with the results of Cohen's 1987 study, the students perceived that teacher feedback focused on local aspects of their writing such as grammar and mechanics; the students wanted more balanced feedback across all aspects of writing, including content and organization as well as grammar and mechanics. Though this study used homogenous subjects, it still has a major limitation in that the number of subjects was extremely small.

Mongomery and Baker (2007) investigated teacher perceptions as well as student perceptions regarding teacher-written feedback. The authors found a large gap between teacher's perceptions about their written feedback and their actual performance: the teachers provided more feedback on local aspects and less feedback on global aspects of student writing (on the first drafts) than their perceptions portrayed. In general, the comparison between teacher perceptions and student perceptions matched well, though students thought they were receiving more feedback than teachers perceived they were giving. Based on the findings, the authors concluded that L2 teachers often tend to be more attentive to students' needs than their beliefs about written feedback.

Moreover, Zhang (1995) examined the perceptions of 81 ESL students regarding their preferences toward various approaches used by teachers to respond to student writing. The study found that the students predominantly favoured teacher feedback over non-teacher feedback (peer feedback or selfevaluation); the results did not support previous arguments that students favour peer feedback over teacher feedback and are frustrated by criticism from teachers. Between peer feedback and selfevaluation, Zhang found that the students preferred the former to the latter. On the other hand, Komura (1999) investigated the perceptions of 65 ESL students regarding teacher feedback, and the results were in line with Leki's (1991) findings in which the students favoured comprehensive over selective feedback. In addition, the study found that the students preferred indirect feedback to direct correction. According to the results, the students were the most concerned with the correct use of verbs and word choice from among the major categories of grammar weaknesses.

The above literature has painted quite a disheartening picture on the impact of teachers' feedback on students' writing. So, are we wasting our time marking students' writing? What we need to acknowledge is the fact that not all our written feedback can help our students improve their writing. Thus, we need to ensure that the time taken to mark our students' writing is time well spent. 


\section{IMPROVING STUDENTS’ WRITING: WHY IS THERE A NEED FOR TEACHER FEEDBACK}

\section{Teachers' role in providing feedback}

The teacher takes on an active role in the editing process in process writing but there has been considerable debate on what type of feedback should be given. According to Radecki and Swales (1988: 72), "there is an emerging consensus among certain L1 and L2 writing researchers that an instructor's time is better spent in attending to textual meaning, rather than to grammatical errors, as a means of aiding students in reshaping their writing". Ferris and Hedgcock (1998) believe that such grammatical corrections are necessary but should not be given on first drafts of multiple draft essays. Comments on earlier drafts should, according to the authors, focus on organization and content rather than grammar. In contrast, Fathman and Whalley found that "grammar and content feedback, whether given alone or simultaneously, positively affect rewriting" (1990, p. 185).

In responsive teaching, the student acts and the teacher react. The range of reaction is extensive and diverse because individual teacher is responding or giving feedback to an individual student, and the students in turn is passing through an ever-changing process of discovery through writing (Murray, 1993). Citing research done by Lynch and Klemans (1978), Reed and Burton (1981), and Burkland and Grimm (1984) on L1 writing, Radecki and Swales (1988, p. 72) note that the students stated a preference for their instructors to edit grammatical and other mechanical errors as they found these comments to be the most helpful. Teachers therefore, need to come up with an effective method of feedback to help students improve their writing.

Teacher's feedback on the idea development, rhetorical structure, style and organization can vary considerable. According to Straub (1996), teachers' comments can either be directive or facilitative, general or specific. However, these responses sometimes do not provide students with a clear understanding of what they are supposed to do when they are revising their text (Zamel, 1985). In order to ensure affective feedbacks are rendered to the student, several issues need to be addressed.

First and foremost, before a teacher can determine how to provide feedback, he or she needs to have a clear understanding of the objectives of the particular writing course taught. Teachers' feedback which does not reflect the writing course objectives may result in students not knowing how to respond appropriately (Williams, 2003).

Another issue that needs to be looked into is on the quantity of errors that a teacher can identify or the quantity of written comments that a teacher can make. Dohrer (1991) feels that teachers should not make too many comments on students' writing. This is because students feel frustrated when they see too many written comments on their paper. Omaggio (1986) believes that it is important for teachers to determine what errors to respond to, as identifying and getting students to correct all the errors can destroy the students' self-esteem and confidence.

Finally, the way teachers write their comments should also be considered. Teachers' written comments need to be detailed and descriptive so that students can understand them. Writing one word comments such as "unclear" or "rewrite" should be avoided (Dohrer, 1991; Bardine 2000). Omaggio (1986) suggests using leading questions, giving hints about what corrections should be made as possible avenues for teachers to help students improve their writing. Positive feedback where the teacher recognises and reinforces what the student has correctly acquired is also believed to be effective in enhancing students' writing skills (Fregeau, 1999). 


\section{IMPROVING STUDENTS’ WRITING: WHY IS THERE A NEED FOR TEACHER FEEDBACK}

\section{Conclusion}

In general, learners need to receive feedback in different ways for different reasons. In fact, ESL teachers should provide meaningful and constructive feedback. Their feedback should deal with all aspects of the learner's writing. This feedback needs to encourage the learner to think about, write and rewrite multiple drafts of each topic. Teacher's feedback needs not focus on direct correction of errors only, but leads the learner to write clearly, unambiguously, logically, and coherently.

Based on studies done on feedback, it is very clear that quality feedbacks by teachers can stimulate students' awareness of their writing as they develop the skills to draft, revise and edit their own work. Lastly, there is also a need to recognize that related factors, like student beliefs, reactions and expectations about the teacher's feedback, constitute a major determinant that influences achievement in writing (Myles, 2004).

In addition, both the absence of personal principles and insufficient knowledge on written feedback might be partly due to lack of training opportunities. Therefore, the provision of sufficient training opportunities on how to provide writing feedback is becoming more crucial for L2 teachers, especially those who regularly respond to a considerable amount of student writing. Given the research findings on L2 written feedback based on studies which focused predominantly on error correction and suggested no one-size-fits-all method, training opportunities such as teacher training programs or workshops about written feedback need to play a more important role in helping L2 teachers acquire knowledge of the various options available and develop a personal philosophy toward the use of corrective feedback.

\section{References}

Allwright, R.L. (1975). Problems in the study of the language teacher's treatment of learner error. In Burt, M. and Dulay, H. (Eds.), New directions in second language learning, teaching and bilingual education: On TESOL (96-109). Washingston, DC: TESOL.

Bardine, B. (2000). Responding to students' writing: A research review and suggestions for ABE and GED teachers. Retrieved on October 1, 2010 from: http://literacy.kent/edu/cra/write.html.

Berg, B. A. M. van den, Admiraal, W. F., and Pilot, A. (2003). Peer assessment in university teaching: An exploration of useful designs. Utrecht University. Retrieved October 1, 2010 from:

http://www.library.uu.nl/digiarchief/dip/diss/2003-0702-105650/inhoud.htm

Berninger, V. W., Fuller, F., \& Whitaker, D. (1996). A process of writing development across life span. Educational Psychology Review, 8(3), 193-218.

Cardelle, M. \& Corno, L. (1981). Effects on second language learning of variations in written feedback on homework assignments. TESOL Quarterly, 15(3), 251-261.

Caulk, N. (1994). Comparing teacher and students responses to written work. TESOL Quarterly, 28(1), $181-187$. 


\section{IMPROVING STUDENTS’ WRITING: WHY IS THERE A NEED FOR TEACHER FEEDBACK}

Clarence Jerry, Moses Samuel and Jariah Mohd. Jan. (2011). Comparing between expert and novice raters in assessing students' written work using verbal protocol analysis. Jurnal Penyelidikan Pendidikan, 2011/2012, 249-280.

Cohen, A. (1987). Student processing of feedback on their compositions. In A. L. Wenden \& J. Rubin (eds.). Learner strategies in second language learning (pp. 57-69). Englewood Cliffs, NJ: Prentice-Hall.

Cohen, A. \& Cavalcanti, M. (1990). Feedback on compositions: Teacher and student verbal reports. In B. Kroll (Ed.), Second Language Writing (pp. 155-177). Cambridge, UK: Cambridge University Press.

Dana, F., Jeffrey, B., Liu, H.S., \& Stine, M. E. A. (2011). Responding to L2 students in college writing classes: Teacher perspectives. TESOL Quarterly, 45(2), 207-234.

Dohrer, G. (1991). Do teachers' comments on students' papers help? College Teaching, 39(2), 48-54.

Ellis, R. (2009). A typology of written corrective feedback types. ELT Journal, 63(2). 97-107.

Fathman, A., \& Whalley, E. (1990). Teacher response to student writing: Focus on form versus content. In B. Kroll (Ed.), Second language writing, research insights for the classroom (pp. 178-188). New York: Cambridge University Press.

Fanselow, J. F. (1977). The treatment of error in oral work. Foreign Language Annals, 10(5), 583593.

Ferris, D. (1997). The influence of teacher commentary on student revision. TESOL Quarterly, 31(2), 315-339.

Ferris, D. R., Pezone, S., Tade, C. R. \& Tinti, S. (1997). Teacher commentary on student writing: Descriptions and implications. Journal of Second Language Writing, 6(2), 155-182.

Ferris, D. (2004). The 'Grammar Correction' debate in L2 writing: Where are we, and where do we go from here? (and what do we do in the meantime. . .?). Journal of Second Language Writing, 13(1), 49-62.

Ferris, D., \& Hedgcock, J. S. (1998). Teaching ESL composition: Purpose, process, and practice. Mahwah, New Jersey: Lawrence Erlbaum Associates, Inc.

Flower, L. S. (1979). Writer-based prose: A cognitive basis for problems in writing. College English, 41(1), 19-37.

Fregeau, L.A. (1999). Preparing ESL students for college writing: Two case studies. The Internet TESL Journal, V(10) (Online).http://iteslj.org/

Frodesen, J. (2001). Grammar in writing. In M. Celce-Murcia (Ed.), Teaching English as a second or foreign language (3rd ed.) (pp. 233-248). Boston, MA: Heinle and Heinle. 


\section{IMPROVING STUDENTS’ WRITING: WHY IS THERE A NEED FOR TEACHER FEEDBACK}

Goldstein, L. M. (2004). Questions and answers about teacher written commentary and student revision: Teachers and students working together. Journal of Second Language Writing 13(1), 63-80.

Goldstein, L. M. (2005). Teacher written commentary in second language writing classrooms. Ann Arbor: The University of Michigan Press.

Graves, D. (1983). Writing: Teachers and children at work. Portsmouth, NH: Heinemann.

Guenette, D. (2007). Is feedback pedagogically correct? Research design issues in studies of feedback on writing. Journal of Second Language Writing, 16(1), 40-53.

Hyland, F. (1998). The impact of teacher written feedback on individual writers. Journal of Second Language Writing, 7(3), 255-286.

Hyland, K. \& Hyland, F. (2006). State-of-the-art review on "Feedback in second language students' writing". Language Teaching, 39(2), 83-101.

Keppner, C. (1991). An experiment in the relationship of types of written feedback to the development of second-language writing skills. Modern Language Journal, 75(3), 305-313.

Kittredge R. (2002). Paraphrasing for condensation in journal abstracting. Journal of Biomedical Informatics, 35(4). 265-277.

Komura, K. (1999). Student response to error correction in ESL classrooms. Master's thesis, California State University, Sacramento.

Lee, I. (2008). Understanding teachers' written feedback practices in Hong Kong secondary classrooms. Journal of Second Language Writing, 17 (2), 69-85.

Leki, I. (1990). Coaching from the margins: Issues in written response. In B. Kroll (Ed.), Second Language Writing. (pp. 57-68). Cambridge: Cambridge University Press.

Leki, I. (1991). The preference of ESL students for error correction in college-level writing classes. Foreign Language Annals, 24(3), 203-218.

Li, V. (1995). Cited in Grundy, P. \& Li, V. (1998). Responding to writing - Options and alternatives. Retrieved on 26 Jun 2006 from http://www.e-mesh.com

McKay, S. L. (1993). Examining composition ideology: A look at literacy education. Journal of Second Language Writing, 2 (1), 65-81.

Myles, J. (2004). Feedback processes in second language writing: Conflict in students and teacher preferences. In Kuldip Kaur \& E. V. Malachi (Eds.), Second language writing. Petaling Jaya, Selangor: Sasbadi Sdn.Bhd.

Moxley, J.M. (1989). Responding to student writing: Gals, methods, alternatives, Freshman English News, 17(2), 3-11. 


\section{IMPROVING STUDENTS' WRITING: WHY IS THERE A NEED FOR TEACHER FEEDBACK}

Montgomery, J. L. \& Baker, W. (2007). Teacher-written feedback: Student perceptions, teacher selfassessment, and actual teacher performance. Journal of Second Language Writing, 16, 8299.

Olson, M. W., \& Raffeld, P. (1987). The effects of written comments on the quality of student compositions and the learning of content. Reading Psychology,8(4), 273-293.

Omaggio, A.C. (1986). Teaching language in context: Proficiency-oriented instruction. Boston: Heinle \& Heinle

Orellana, M. F. (1995). Literacy as a gendered social practice: Tasks, texts, talk, and take-up. Reading Research Quarterly, 30(4), 674-708.

Patthey-Chavez, G. G., \& Clare, L. (1996). Task, talk, and text: The influence of instructional conversation on transitional bilingual writers. Written Communication, 13(4), 515-563.

Radecki, P., and Swales, J. (1988). ESL student reaction to written comments on their written work. System, 16(3), 355-365.

Robb, T., Ross, S. \& Shortreed, I. (1986). "Salience of feedback on error and its effect on EFL writing quality". In TESOL Quarterly, 20(1), .83-93.

Sarah, G., Lies, T., Filip, D., Onghena, P., \& Stijn, S. (2010). A Comparative Study of Peer and Teacher Feedback and of Various Peer Feedback Forms in a Secondary School Writing Curriculum. British Educational Research Journal, 36(1), 143-162.

Semke, H. H. (1984). 'The effect of the red pen’. In Foreign Language Annals, 17(3), 195-202.

Sommers, N. (1982). Responding to students writing. College Composition and Communication, .33, 148-156.

Swain, M. (1995). Three functions of output in second language learning. In Cook, G. and Seidlhofer, B. (Eds.), Principles and Practice in Applied Linguistics: Studies in honour of $H$. G. Widdowson (pp. 125-144). New York: Oxford University Press.

Straub, R. (1997). Students' reactions to teacher comments: An exploratory study, Research in the Teaching of English, 31(1), 91-119.

Williams, J. G. (2003). Providing feedback on ESL students' written assignments. The Internet TESL Journal, 4(10).

Wollman-Bonilla, J. E. (2000). Teaching science writing to first graders: Genre learning and recontextualization. Research in the Teaching of English, 35(1), 35-65.

Zak, F. (1990). Exclusively positive responses to student writing, Journal of Basic Writing, 9(2), 4053.

Zamel, V. (1985). Responding to student writing. TESOL Quarterly, 19(1), 79-102. 


\section{IMPROVING STUDENTS' WRITING: WHY IS THERE A NEED FOR TEACHER FEEDBACK}

Zellermayer, M. (1989). The study of teachers' written feedback to student writing: Changes in the theoretical considerations and the expansion of research contexts. Instructional Science, 18(2), 145-165.

Zhang, S. (1995). Reexamining the affective advantage of peer feedback in the ESL writing class. Journal of Second Language Writing, 4(3), 209-222. 